\title{
Effect of template size on microstructure and strength of porous silicon carbide ceramics
}

\author{
Jung-Hye EOM and Young-Wook KIM ${ }^{\dagger}$ \\ Department of Materials Science and Engineering, the University of Seoul, \\ 90 Jeonnong-dong, Dongdaemoon-gu, Seoul 130-743, Republic of Korea
}

\begin{abstract}
Porous silicon carbide $(\mathrm{SiC})$ ceramics with different pore size were prepared from $\mathrm{SiC}$ powders, an aluminum yttrium garnet $\left(\mathrm{Y}_{3} \mathrm{Al}_{5} \mathrm{O}_{12}, \mathrm{YAG}\right)$ as a sintering additive, and three different sizes of templates (polymer microbeads) by a sacrificial template technique. Their microstructure and mechanical strengths were evaluated as a function of template size, i.e., pore size. Porosity of these porous $\mathrm{SiC}$ ceramics increased with increasing the template content, regardless of template size. Pore size was proportional with the template size. The growth of faceted grains was accelerated with increasing the template size. Both flexural and compressive strengths decreased with increasing the porosity whereas both strengths increased with decreasing the template size, i.e., pore size. Typical flexural and compressive strengths of the porous SiC ceramics fabricated using $8 \mu \mathrm{m}$-templates were $\sim 55 \mathrm{MPa}$ and $\sim 240 \mathrm{MPa}$ at $\sim 45 \%$ porosity, respectively.
\end{abstract}

(C2008 The Ceramic Society of Japan. All rights reserved.

Key-words : Silicon carbide, Porosity, Microstructure, Strength, Porous ceramics

[Received May 1, 2008; Accepted July 17, 2008]

\section{Introduction}

Porous silicon carbide $(\mathrm{SiC})$ ceramics are attracting considerable interest because of their great potential for a number of industrial applications such as catalytic supports, molten metal filters, diesel particulate filters, membrane supports for hydrogen separation, gas-burner media, and preforms for metal matrix composites. ${ }^{1)-5)}$ Depending on the requirements of a given application, the porous ceramics must exhibit specific pore morphology, porosity, and different mechanical properties. Obviously, the processing techniques used to develop porous ceramics must result in well-controlled microstructures and yield mechanical properties that render the material serviceable for a specific application.

The effect of porosity on compressive and flexural strengths of porous $\mathrm{SiC}$ ceramics was investigated by several researchers. ${ }^{2), 6), 7)}$ According to a model proposed by Gibson and Ashby, ${ }^{8)}$ the relative strength of a cellular material showing brittle crushing behavior is related to its relative density through the expression

$$
\left(\sigma / \sigma_{\mathrm{o}}\right) \propto C\left(\rho / \rho_{\mathrm{o}}\right)^{m}
$$

where $\sigma_{\mathrm{o}}$ and $\rho_{\mathrm{o}}$ are strength and true density of cell-wall material, $\sigma$ and $\rho$ are strength and density of cellular material, and $C$ is a dimensionless constant. According to a model proposed by Rice ${ }^{9)}$ the strength of a porous material is related to its porosity through the expression

$$
\sigma=\sigma_{\mathrm{o}} \exp (-b P)
$$

where $\sigma_{\mathrm{o}}$ and $\sigma$ are the strength of a nonporous material and the strength of the porous material with a porosity $P$, respectively, and $b$ is a constant that is dependent on the pore characteristics. Both models do not expect any dependence of the strength on pore size, but a variation only with the porosity of the porous ceramics. However, it is expected that the pore size affects the

Corresponding author: Y.-W. Kim; E-mail: ywkim@uos.ac.kr strength of porous ceramics. The effect of pore size on strength of porous $\mathrm{SiC}$ ceramics has not been investigated systematically.

In this study, the effect of pore size on microstructure and strength of porous $\mathrm{SiC}$ ceramics were investigated. To fabricate the porous $\mathrm{SiC}$ ceramics with the same porosity but different pore size, a sacrificial template technique was adopted using three different sizes of templates $(8 \mu \mathrm{m}, 20 \mu \mathrm{m}$, and $50 \mu \mathrm{m})$. By controlling the template content, it was possible to adjust the porosity ranging from $16 \%$ to $57 \%$.

\section{Experimental procedure}

Commercially available $\alpha$-SiC (A1 grade, Showa Denko, Tokyo, Japan), $\beta$-SiC (Ultrafine grade, Betarundum, Ibiden., Ogaki, Japan), $\mathrm{Y}_{3} \mathrm{Al}_{5} \mathrm{O}_{12}$ (99.9\%, High Purity Chemicals, Inc., Tokyo, Japan, hereafter YAG), and poly(methyl methacrylate-coethylene glycol dimethacrylate) microbeads $(\sim 8 \mu \mathrm{m}, \sim 20 \mu \mathrm{m}$, $\sim 50 \mu \mathrm{m}$, Sigma-Aldrich Inc, St. Louis, MO, hereafter polymer microbeads) were used as raw materials. The mean particle sizes of the $\alpha$ - and $\beta$-SiC powders were 0.45 and $0.27 \mu \mathrm{m}$, respectively. The $\alpha$-SiC and YAG were added as a seed for the $\beta \rightarrow \alpha$ phase transformation of $\mathrm{SiC}$ and a sintering additive, respectively. Thirteen batches of powder mixtures were prepared and the template content in those batches ranged from 0 to 30 mass $\%$ (Table 1). The size and content of template were varied from 8 to $50 \mu \mathrm{m}$ and from 0 to 30 mass $\%$, respectively. As an organic binder, 3 mass $\%$ polyethylene glycol was added to each batch. An example of sample notation is: SC20-8 denotes a sample containing 20 mass $\%$ polymer microbeads with an average diameter of $8 \mu \mathrm{m}$ as a sacrificial template. All individual batches were mixed in ethanol for $24 \mathrm{~h}$ using $\mathrm{SiC}$ balls and a polyethylene jar. The milled slurry was dried and uniaxially pressed into rectangular hexahedrons at $50 \mathrm{MPa}$. The green compacts were heattreated in nitrogen at $450^{\circ} \mathrm{C}$ for $1 \mathrm{~h}$ and subsequently at $800^{\circ} \mathrm{C}$ for $1 \mathrm{~h}$ with a heating rate of $2^{\circ} \mathrm{C} / \mathrm{min}$. The heat treatment enables the decomposition of polymer microbeads, resulting in cellular SiC ceramics. The heat-treated compacts were further 
sintered at $1850^{\circ} \mathrm{C}$ for $1 \mathrm{~h}$ with a heating rate of $20^{\circ} \mathrm{C} / \mathrm{min}$ in argon and subsequently annealed at $1950^{\circ} \mathrm{C}$ for $4 \mathrm{~h}$ for the $\beta \rightarrow \alpha$ phase transformation of $\mathrm{SiC}$ and grain growth. ${ }^{10)}$

The porosity of the porous ceramics was calculated from the bulk density $\left(D_{\mathrm{b}}\right)$ of the porous ceramics and the theoretical density $\left(D_{\mathrm{th}}, 3.349 \mathrm{~g} / \mathrm{cm}^{3}\right)$ of the strut material according to

$$
\text { Porosity }(\%)=\left(1-D_{\mathrm{b}} / D_{\mathrm{th}}\right) \times 100
$$

Thus, the porosity includes both the porosity from microbead and the porosity from the strut. The pore morphology was observed by scanning electron microscopy (SEM). Using $\mathrm{Cu} \mathrm{K} \alpha$ radiation, X-ray diffractometry (XRD) was performed on some selected specimens. The flexural strength was measured by fourpoint bending with an inner and outer span of $10 \mathrm{~mm}$ and $20 \mathrm{~mm}$, respectively, on samples with a size of $4 \mathrm{~mm} \times 5 \mathrm{~mm} \times 30 \mathrm{~mm}$. The compressive strength was measured on samples with a size of $4 \mathrm{~mm} \times 4 \mathrm{~mm} \times 8 \mathrm{~mm}$. The cross-head speed for measuring both strengths was $0.5 \mathrm{~mm} / \mathrm{min}$.

\section{Results and discussion}

The heating up of the $\mathrm{SiC}$ powder compacts containing polymer microbeads to $800^{\circ} \mathrm{C}$ followed by isothermal holding at the temperature and subsequent heat-treatment at $1850^{\circ} \mathrm{C}$ for $1 \mathrm{~h}$ allows (1) burn-out of the polymer microbeads, leaving spherical pores in the compacts and (2) liquid-phase sintering of $\mathrm{SiC}$ powders, forming a $\mathrm{YAG}-\mathrm{SiO}_{2}$-derived liquid phase as a bonding phase between $\mathrm{SiC}$ particles, resulting in porous $\mathrm{SiC}$ ceramics. Subsequent annealing at $1950^{\circ} \mathrm{C}$ for $4 \mathrm{~h}$ leads to the formation

Table 1. Batch Composition

\begin{tabular}{lc}
\hline Sample designation & \multicolumn{1}{c}{ Batch composition (mass $\%)$} \\
\hline $\mathrm{SC} 0$ & $85.60 \% \beta-\mathrm{SiC}+0.90 \% \alpha-\mathrm{SiC}+13.50 \% \mathrm{Y}_{3} \mathrm{Al}_{5} \mathrm{O}_{12}$ \\
$\mathrm{SC} 5-8$ & $81.32 \% \beta-\mathrm{SiC}+0.86 \% \alpha-\mathrm{SiC}+12.83 \% \mathrm{Y}_{3} \mathrm{Al}_{5} \mathrm{O}_{12}+5.00 \%$ microbead $(\sim 8 \mu \mathrm{m})^{*}$ \\
$\mathrm{SC} 10-8$ & $77.04 \% \beta-\mathrm{SiC}+0.81 \% \alpha-\mathrm{SiC}+12.15 \% \mathrm{Y}_{3} \mathrm{Al}_{5} \mathrm{O}_{12}+10.00 \%$ microbead $(\sim 8 \mu \mathrm{m})^{*}$ \\
$\mathrm{SC} 20-8$ & $68.48 \% \beta-\mathrm{SiC}+0.72 \% \alpha-\mathrm{SiC}+10.80 \% \mathrm{Y}_{3} \mathrm{Al}_{5} \mathrm{O}_{12}+20.00 \%$ microbead $(\sim 8 \mu \mathrm{m})^{*}$ \\
$\mathrm{SC} 30-8$ & $59.92 \% \beta-\mathrm{SiC}+0.63 \% \alpha-\mathrm{SiC}+9.45 \% \mathrm{Y}_{3} \mathrm{Al}_{5} \mathrm{O}_{12}+30.00 \%$ microbead $(\sim 8 \mu \mathrm{m})^{*}$ \\
$\mathrm{SC} 5-20$ & $81.32 \% \beta-\mathrm{SiC}+0.86 \% \alpha-\mathrm{SiC}+12.83 \% \mathrm{Y}_{3} \mathrm{Al}_{5} \mathrm{O}_{12}+5.00 \%$ microbead $(\sim 20 \mu \mathrm{m})^{*}$ \\
$\mathrm{SC} 10-20$ & $77.04 \% \beta-\mathrm{SiC}+0.81 \% \alpha-\mathrm{SiC}+12.15 \% \mathrm{Y}_{3} \mathrm{Al}_{5} \mathrm{O}_{12}+10.00 \%$ microbead $(\sim 20 \mu \mathrm{m})^{*}$ \\
$\mathrm{SC} 20-20$ & $68.48 \% \beta-\mathrm{SiC}+0.72 \% \alpha-\mathrm{SiC}+10.80 \% \mathrm{Y}_{3} \mathrm{Al}_{5} \mathrm{O}_{12}+20.00 \%$ microbead $(\sim 20 \mu \mathrm{m})^{*}$ \\
$\mathrm{SC} 30-20$ & $59.92 \% \beta-\mathrm{SiC}+0.63 \% \alpha-\mathrm{SiC}+9.45 \% \mathrm{Y}_{3} \mathrm{Al}_{5} \mathrm{O}_{12}+30.00 \%$ microbead $(\sim 20 \mu \mathrm{m})^{*}$ \\
$\mathrm{SC} 5-50$ & $81.32 \% \beta-\mathrm{SiC}+0.86 \% \alpha-\mathrm{SiC}+12.83 \% \mathrm{Y}_{3} \mathrm{Al}_{5} \mathrm{O}_{12}+5.00 \%$ microbead $(\sim 50 \mu \mathrm{m})^{*}$ \\
$\mathrm{SC} 10-50$ & $77.04 \% \beta-\mathrm{SiC}+0.81 \% \alpha-\mathrm{SiC}+12.15 \% \mathrm{Y}_{3} \mathrm{Al}_{5} \mathrm{O}_{12}+10.00 \%$ microbead $(\sim 50 \mu \mathrm{m})^{*}$ \\
$\mathrm{SC} 20-50$ & $68.48 \% \beta-\mathrm{SiC}+0.72 \% \alpha-\mathrm{SiC}+10.80 \% \mathrm{Y}_{3} \mathrm{Al}_{5} \mathrm{O}_{12}+20.00 \%$ microbead $(\sim 50 \mu \mathrm{m})^{*}$ \\
$\mathrm{SC} 30-50$ & $59.92 \% \beta-\mathrm{SiC}+0.63 \% \alpha-\mathrm{SiC}+9.45 \% \mathrm{Y}_{3} \mathrm{Al}_{5} \mathrm{O}_{12}+30.00 \%$ microbead $(\sim 50 \mu \mathrm{m})^{*}$ \\
\hline
\end{tabular}

*Poly (methyl methacrylate-co-ethylene glycol dimethacrylate) microbead, Sigma-Aldrich Inc, St. Louis, MO, USA.
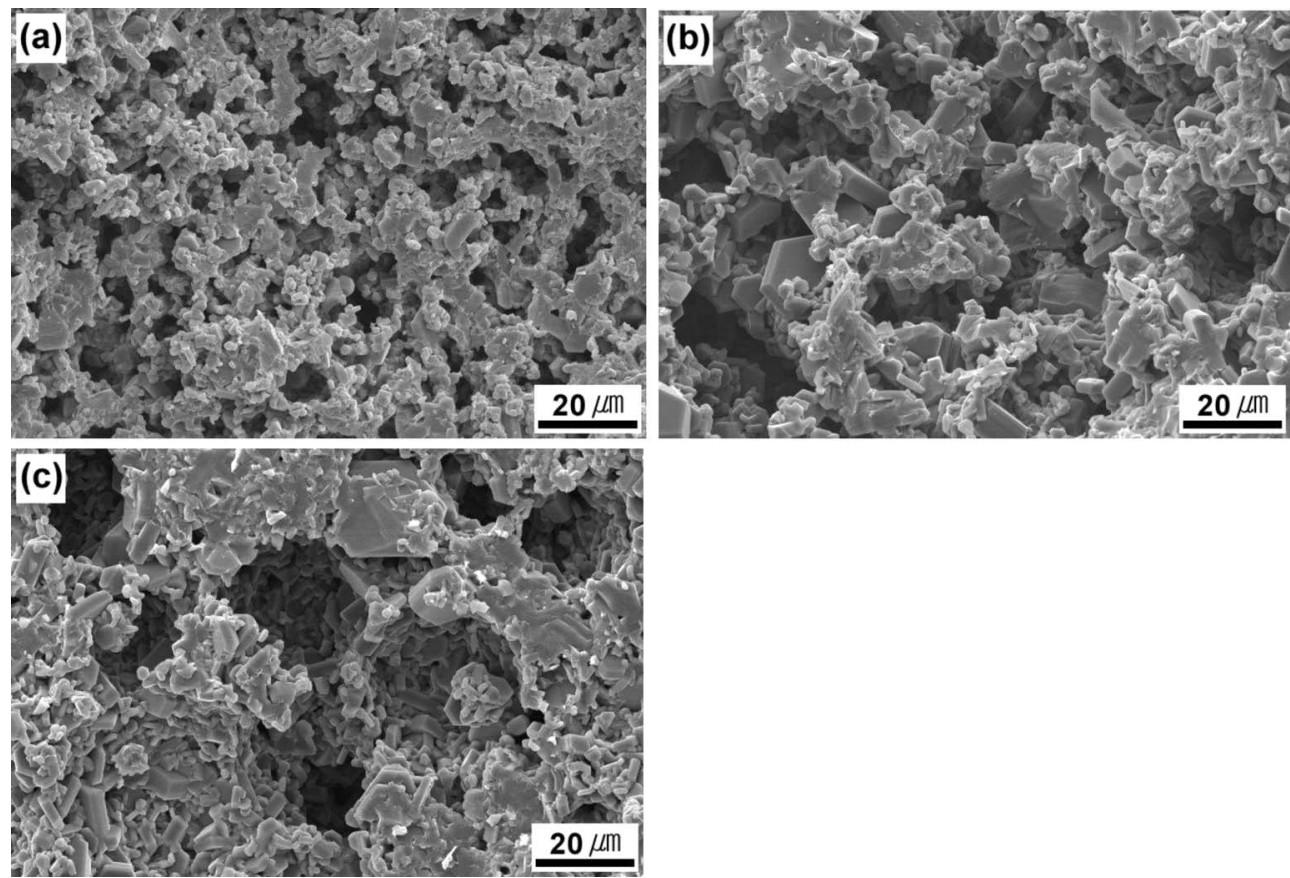

Fig. 1. Typical fracture surfaces of porous silicon carbide ceramics sintered at $1850^{\circ} \mathrm{C}$ for $1 \mathrm{~h}$ and subsequently annealed at $1950^{\circ} \mathrm{C}$ for $4 \mathrm{~h}$ in argon: (a) SC20-8, (b) SC20-20 and (c) SC20-50 (refer to Table 1). 

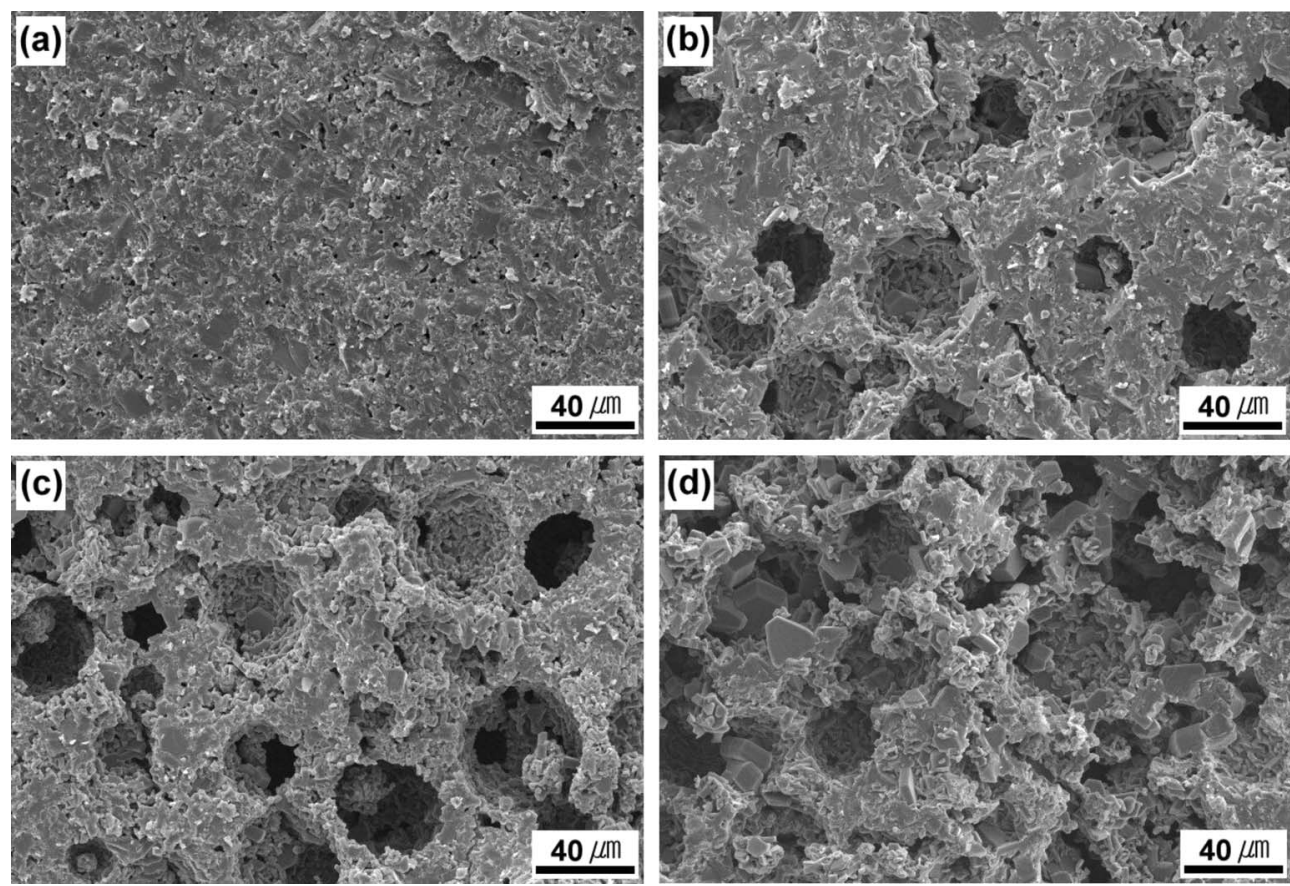

Fig. 2. Effect of microbead content on fracture surface of porous silicon carbide ceramics sintered at $1850^{\circ} \mathrm{C}$ for $1 \mathrm{~h}$ and subsequently annealed at $1950^{\circ} \mathrm{C}$ for $4 \mathrm{~h}$ in argon: (a) SC0, (b) SC5-50, (c) SC20-50 and (d) SC30-50 (refer to Table 1).

of platelet $\alpha-\mathrm{SiC}$ grains by the $\beta \rightarrow \alpha$ phase transformation of $\mathrm{SiC}$ and grain growth. Phase analysis by XRD confirmed the presence of $\alpha-\mathrm{SiC}$ and $\beta$-SiC as crystalline phases, indicating the occurrence of the $\beta \rightarrow \alpha$ phase transformation of $\mathrm{SiC}$ during annealing. However, the intensity of $\alpha$-SiC peaks became stronger when larger templates were added.

Typical fracture surfaces of the porous $\mathrm{SiC}$ ceramics are shown in Fig. 1. As shown, open cells were formed for SC20-8 and SC20-20 specimens, but partially-interconnected, open-cells were formed for SC20-50 specimens. This figure shows evidence that well-distributed pores were achieved, and that moderately dense struts in the cellular structure were also produced. The morphology of the primary pores (pores replicated from templates) was almost spherical, indicating that the shape of the polymer microbeads is retained in the SiC-YAG-polymer microbead compact up to its decomposition temperature. The primary pore sizes of SC20-8, SC20-20, and SC20-50 specimens were 7 $\pm 3 \mu \mathrm{m}, 14 \pm 6 \mu \mathrm{m}$, and $31 \pm 12 \mu \mathrm{m}$, respectively. The average pore size in the porous $\mathrm{SiC}$ ceramics is proportional to the template size that was used to produce the pores, as expected. The scattering in the data reflects the size distribution in the starting microbeads. There are no large voids in the bulk materials. This suggest that the proposed processing method is capable of preventing significant agglomeration of the polymer microbeads and, at the same time, allows for the homogeneous distribution of the $\mathrm{SiC}$ and the sintering additive among the sacrificial templates.

Effect of template content on microstructure is shown in Fig. 2. The number of primary pores increased with increasing the template content. The pore morphology changed from spherical to distorted sphere-shape as the template content increases in the porous $\mathrm{SiC}$ ceramics. This change was due to the greater opportunity for contact between the templates in the compacts (Fig. 2(d)). Microstructural features, including average grain sizes of equiaxed and platelet grains, almost do not change with the con-

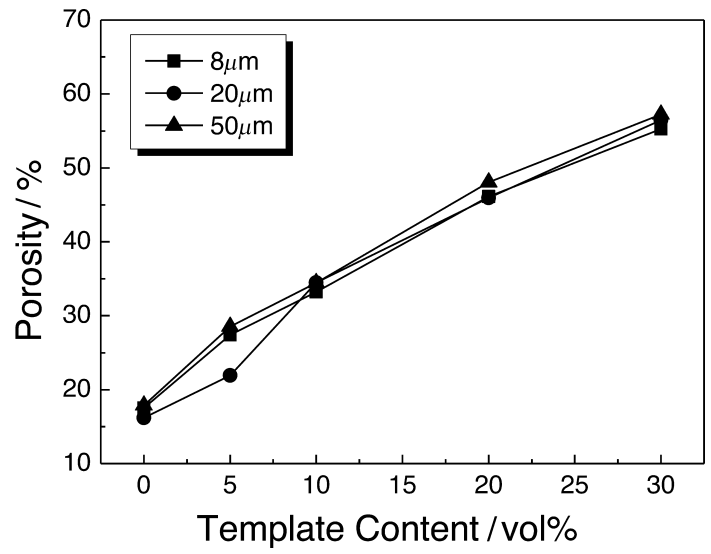

Fig. 3. Effect of microbead content on porosity of porous silicon carbide ceramics sintered at $1850^{\circ} \mathrm{C}$ for $1 \mathrm{~h}$ and subsequently annealed at $1950^{\circ} \mathrm{C}$ for $4 \mathrm{~h}$ in argon.

tent of microbead. Only the sample with the highest microbead content (30 mass\%, Fig. 2(d)) shows some difference from the others, exhibiting some larger platelet grains, which give a typical bimodal microstructure. ${ }^{11)}$ The growth of the large platelet grains in the specimen was promoted because of more space available in the pores (see Fig. 2(d)).

Figure 3 shows the porosity of porous $\mathrm{SiC}$ ceramics as a function of the size and content of template. The porosities of the ceramics ranged from $17 \%$ to $57 \%$, depending on the template content. The porosity increased linearly with increasing the template content, but the porosity almost did not change with the size of template at the same content of template. Thus, the porous ceramics have almost same porosity at the same content of template, but different pore size.

Figure 4 shows the typical grain morphology of porous $\mathrm{SiC}$ 

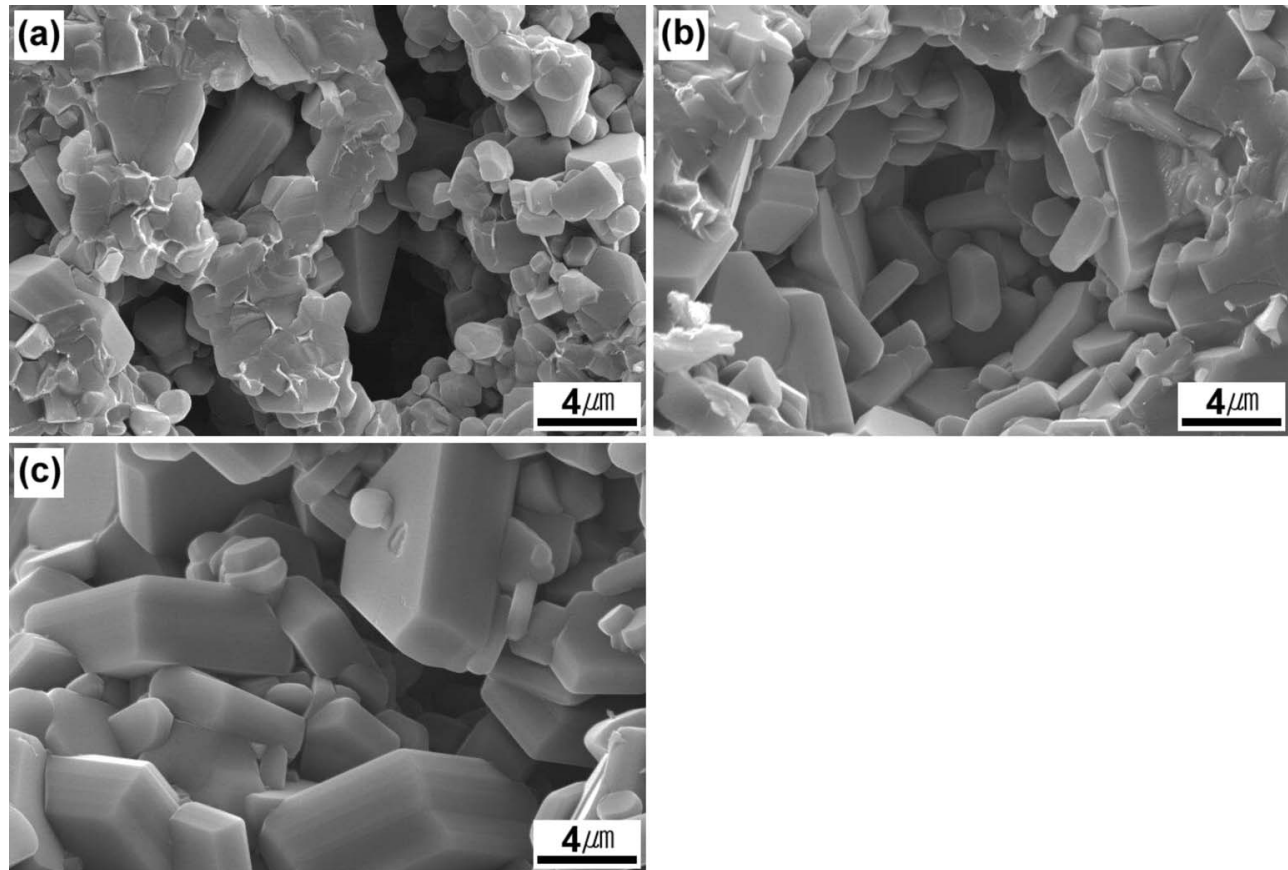

Fig. 4. Typical grain morphology of porous silicon carbide ceramics sintered at $1850^{\circ} \mathrm{C}$ for $1 \mathrm{~h}$ and subsequently annealed at $1950^{\circ} \mathrm{C}$ for $4 \mathrm{~h}$ in argon: (a) SC10-8, (b) SC10-20 and (c) SC10-50 (refer to Table 1).

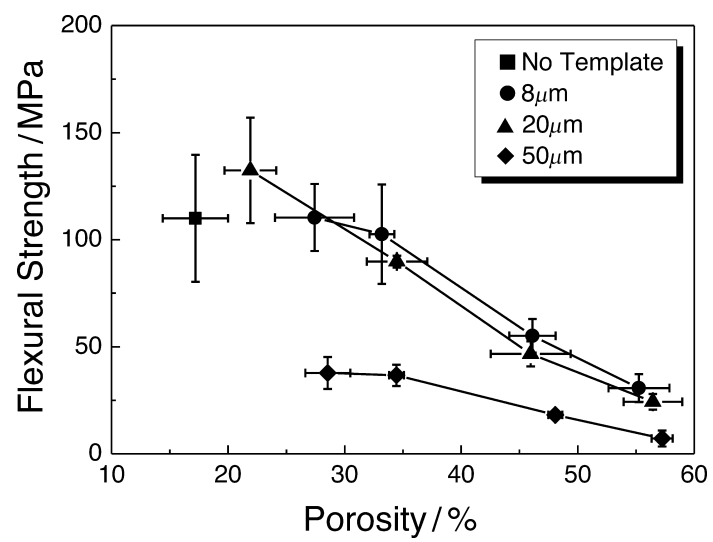

Fig. 5. Effects of template size and porosity on flexural strength of porous silicon carbide ceramics.

ceramics. Two kinds of grain morphology were observed: equiaxed and platelet grains. The equiaxed grains are considered to be a mixture of $\beta$ - and $\alpha$-SiC phases. ${ }^{11)-13)}$ In contrast, the platelet grains are considered to be $\alpha$-SiC. ${ }^{14)} \mathrm{SC} 10-8$ specimen consisted of equiaxed grains and platelet grains (Fig. 4(a)). In contrast, SC10-50 specimen consisted of mostly well-faceted platelet grains. Furthermore, the size of platelet grains increased with increasing the template size. The growth of the large platelet grains was promoted because of more space available in the pores (see Fig. 4(c)). This result is consistent with the result observed in the highest amount of template content (SC30-50, Fig. 2(d)). It is clear that open space like pores makes a good environment for the growth of large platelet grains because of no impingement ${ }^{15)}$ and the enhanced mass transport.

Figures 5 and $\mathbf{6}$ show the flexural and compressive strength data for the porous $\mathrm{SiC}$ ceramics as a function of template size and porosity. The strength decreased with increasing porosity.

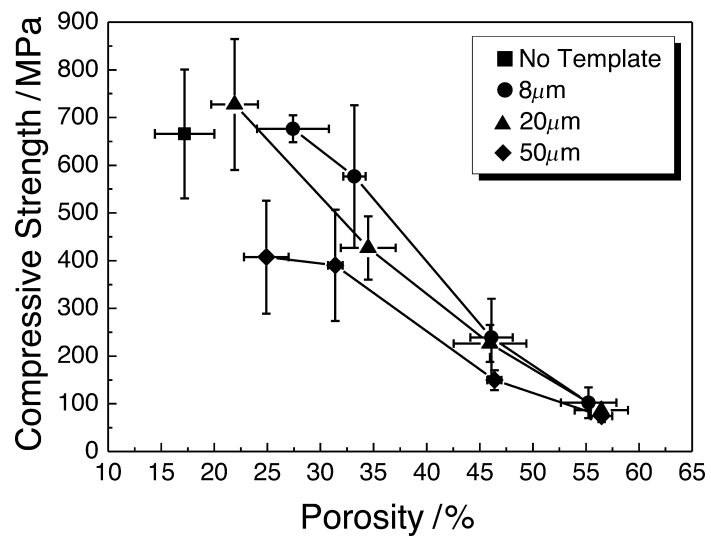

Fig. 6. Effects of template size and porosity on compressive strength of porous silicon carbide ceramics.

This tendency has been observed in many other porous ceramics $^{16)-18)}$ and was attributed to the higher probability of pore coalescence at the higher porosity under load. The pore coalescence leads to a larger critical flaw size, resulting in a lower strength. Typical flexural and compressive strengths of the porous $\mathrm{SiC}$ ceramics fabricated using $8 \mu \mathrm{m}$-templates were $\sim 105$ $\mathrm{MPa}$ and $\sim 600 \mathrm{MPa}$ at $\sim 30 \%$ porosity, respectively.

According to models proposed by Gibson and Ashby ${ }^{8)}$ and by Rice, ${ }^{9)}$ any dependence of the strength on the pore size was not expected, but a variation only with the porosity of porous ceramics. However, our results showed that the strength of the porous $\mathrm{SiC}$ ceramics decreased with increasing the template size, e.g., pore size at the same porosity. The porous $\mathrm{SiC}$ ceramics fabricated here showed dense strut (see Fig. 4) and homogeneous distribution of pores throughout the specimens (Fig. 2). Thus, our results can be explained in terms of (1) an increase in strut strength with decreasing the pore-to-pore distance when smaller 
templates were used for a given amount of porosity, owing to a statistical distribution of flaws in the ceramics, and (2) a decrease in the critical flaw size when smaller templates were used. Similar trends were observed also for foamed glass, ${ }^{19)}$ carbon foams, ${ }^{20)}$ and SiOC foams. ${ }^{21)}$

Typical flexural strengths of the porous $\mathrm{SiC}$ ceramics with $\sim 45 \%$ porosity were $\sim 55 \mathrm{MPa}$ for SC20-8, $47 \mathrm{MPa}$ for SC2020 , and $20 \mathrm{MPa}$ for SC20-50 specimens. Flexural strengths of $\sim 10 \mathrm{MPa}$ at $\sim 50 \%$ porosity $^{22)}$ and $\sim 28 \mathrm{MPa}$ at $\sim 44 \%$ porosity $^{23)}$ have been reported in reaction-bonded porous $\mathrm{SiC}$ ceramics. Typical compressive strengths of our samples with $\sim 45 \%$ porosity were $\sim 240 \mathrm{MPa}$ for SC20-8, 227 MPa for SC20-20, and 150 MPa for SC20-50 specimens. Typical compressive strength of $\sim 160 \mathrm{MPa}$ was reported at $40 \%$ porosity in porous $\mathrm{SiC}$ ceramics prepared using $\sim 20 \mu \mathrm{m}$ microbeads as the sacrificial template. ${ }^{24)}$

Our samples fabricated using small templates $(8 \mu \mathrm{m}$ and 20 $\mu \mathrm{m})$ have superior strengths than the literature data, whereas our samples fabricated using relatively large templates $(50 \mu \mathrm{m})$ have equal to or lower than the literature data. Our data is comparable with the flexural and compressive strength values ( 60 MPa and $\sim 240 \mathrm{MPa}$, respectively, at $40 \%$ porosity) measured in polysiloxane-derived $\mathrm{SiC}$ ceramics that was fabricated using hollow microspheres with an average diameter of $\sim 20 \mu \mathrm{m}$. ${ }^{7)}$ Direct comparison between the present and the literature data could not be made because of differences in material type (sintered $\mathrm{SiC}$ versus reaction-bonded $\mathrm{SiC}$ ) and in additive composition (YAG versus $\mathrm{Al}_{2} \mathrm{O}_{3}-\mathrm{Y}_{2} \mathrm{O}_{3}$ ). However, it is clear that when the same processing and the same composition were used, the smaller template resulted in the higher strength at the same porosity in the porous $\mathrm{SiC}$ ceramics. Ding et $\mathrm{al}^{23)}$ used graphite particles $(\sim 20 \mu \mathrm{m})$ as a template for fabricating porous $\mathrm{SiC}$ ceramics, and the resulting strength of the ceramics was $\sim 28 \mathrm{MPa}$ at $\sim 44 \%$. In contrast, typical flexural strength of our samples fabricated with spherical template $(\sim 20 \mu \mathrm{m})$ was $\sim 47 \mathrm{MPa}$ at $\sim 45 \%$ porosity. Graphite particles are not as spherical as polymer microbeads used in the present study. Thus, spherical template should be beneficial than the other shapes with respect to the mechanical strength. These results suggest that spherical templates with a small diameter $(\leq$ $20 \mu \mathrm{m}$ ) would be beneficial for preparing high-strength, porous $\mathrm{SiC}$ ceramics.

\section{Conclusions}

By using SiC powders, YAG as a sintering additive, and polymer microbeads as a sacrificial template, it was possible to fabricate porous $\mathrm{SiC}$ ceramics with a uniform and well distributed porosity, in which the average pore size varied from $\sim 7-31 \mu \mathrm{m}$. The growth of the large platelet grains was promoted when large $(\sim 50 \mu \mathrm{m})$ templates were used because of more space available in the pores. The flexural and compressive strengths increased with decreasing the pore size, because of an increase in strut strength and a decrease in the critical flaw size when smaller templates were used. Spherical templates with a small diameter would be beneficial for preparing high-strength, porous $\mathrm{SiC}$ ceramics. Typical flexural and compressive strengths of the porous SiC ceramics fabricated using $8 \mu$ m-templates were $\sim 105$ $\mathrm{MPa}$ and $\sim 600 \mathrm{MPa}$ at $\sim 30 \%$ porosity, respectively.

Acknowledgment This work was supported by a Research Grant of the University of Seoul in 2007.

\section{References}

1) V. Suwanmethanond, E. Goo, P. K. T. Liu, G. Johnston, M. Sahimi and T. T. Tsotsis, Ind. Eng. Chem. Res., 39, 3264-3271 (2000).

2) X. Zhu, D. Jiang and S. Tan, Mater. Sci. Eng. A, 323, 232238 (2002).

3) S. Kitaoka, Y. Matsushima, C. Chen and H. Awaji, J. Am. Ceram. Soc., 87, 906-913 (2004).

4) J. Adler, Int. J. Appl. Ceram. Technol., 2, 429-439 (2005).

5) M. Fukushima, Y. Zhou, H. Miyazaki, Y. Yoshizawa, K. Hirao, Y. Iwamoto, S. Yamazaki and T. Nagano, J. Am. Ceram. Soc., 89, 1523-1529 (2006).

6) L. Esposito, D. Sciti, A. Piancastelli and A. Bellosi, J. Eur. Ceram. Soc., 24, 533-540 (2004).

7) J. H. Eom, Y.-W. Kim, I. H. Song and H. D. Kim, J. Eur. Ceram. Soc., 28, 1029-1035 (2008).

8) L. J. Gibson and M. F. Ashby, Cellular Solids, Cambridge University Press, Cambridge (1999) pp. 210-214.

9) R. W. Rice, J. Mater. Sci., 28, 2187-2190 (1993).

10) J. H. Lee, D.-Y. Kim and Y.-W. Kim, J. Eur. Ceram. Soc., 26, 1267-1272 (2006).

11) Y. Hirata, N. Matsunaga, N. Hidaka, S. Tabata and S. Sameshima, J. Ceram. Soc. Japan, 116, 665-673 (2008).

12) H. Tanaka, T. Nishimura, N. Hirosaki and D. H. Jeong, $J$. Ceram. Soc. Japan, 113, 51-54 (2005).

13) Y.-W. Kim, M. Mitomo, H. Emoto and J. G. Lee, J. Am. Ceram. Soc., 81, 3136-3140 (1998).

14) S. G. Lee, Y.-W. Kim and M. Mitomo, J. Am. Ceram. Soc., 84, 1347-1353 (2001).

15) Y.-W. Kim, M. Mitomo and H. Hirotsuru, J. Am. Ceram. Soc., 78, 3145-3148 (1995).

16) P. Colombo, J. R. Hellmann and D. L. Shelleman, J. Am. Ceram. Soc., 84, 2245-2251 (2001).

17) A. Herzog, U. Vogt, O. Kaczmarek, R. Klingner and K. Richter, J. Am. Ceram. Soc., 89, 1499-1503 (2006).

18) D. H. Jang, Y.-W. Kim, I. H. Song and H. D. Kim, J. Am. Ceram. Soc., 89, 3262-3265 (2006).

19) J. S. Morgan, J. L. Wood and R. C. Bradt, Mater. Sci. Eng., 47, 37-42 (1981).

20) R. Brezny and D. J. Green, Acta Metall. Mater., 38, 25172526 (1990).

21) P. Colombo, E. Bernardo and L. Biasetto, J. Am. Ceram. Soc., 87, 152-154 (2004).

22) S. Ding, Y. P. Zeng and D. Jiang, Mater. Sci. Eng. A, 425, 326-329 (2006).

23) S. Ding, S. Zhu, Y. Zeng and D. Jiang, Ceram. Int., 32, 461466 (2006).

24) S. H. Lee and Y.-W. Kim, J. Kor. Ceram. Soc., 43, 458-462 (2006). 